\title{
Development of Rice Husk and Egg Shell Fillers in Polymer Composites: A Review
}

\author{
Anjana S \\ Research Scholar \\ Department of chemistry,Mar Thoma College \\ Mahatma Gandhi University,Kottayam, Kerala, India
}

\author{
Dr. Shaji P Thomas \\ Research Guide \&Associate Professor \\ Department of Chemistry \\ Bishop Abraham Memorial College \\ Thuruthicad,Kerala, India
}

\begin{abstract}
Natural fibers such as hemp, sisal, jute, cotton,flax and broom are the most commonly used fibers for the reinforcement of polymers. These bio fillers are used in polymeric compound because of its low cost and bio degradable nature. This review gives the information about bio fillers rice husk and egg shell used in polymer technology and importance of this bio fillers in science and technology area.
\end{abstract}

Keywords:- Rice husk ash;Egg shell; Bio fillers; Natural fiber; Elastomer; Mechanical Properties;

\section{INTRODUCTION}

Due to high prize of petroleum product and its environmental hazards,now a days petroleum based fillers, are used very less.Most of the researchers promote environmental friendly bio fillers for polymer field. Now, many food wastes as a bio fillers, which is incorporated with various polymers like thermoplastic,thermosetting plastic, elastomers etc. Natural fibers such as hemp, sisal, jute, cotton,flax and broom are the most commonly used fibers for the reinforcement of polymers. These biofillers are used in polymeric compound because of its low cost and bio degradable nature.Due to the above advantages of biofiller many researches focuss their work in biofillers field.Based on the review biofillers optained from natural fiber (wheat straw, corn stalks,hemp, flax, jute, linen, kenaf, coconut; oil palm, banana,pineapple, and sugarcane)eggshell, shellfish shell, shrimp shell etc. were received a considerable attention in the last few years.In this review give the information about biofillers rice husk and egg shell used in polymer technology and importance of this biofillers in science and technology area.

\section{BIOFILLER RICE HUSK}

Rice is one of the most important food crops in the world. Paddy cultivation is a part of the proud culture of India. Rice husk is an agricultural waste from paddy field .Its disposal still represents an environmental issue [12] .Rotting of rice husk in the paddy field will produce methane gas (potent green house gas)which may cause global warming and badly affect climate [3]. The annual world production of rice is approximately 670 million metric tons. RH is a cellulose-based fibrous materials. The major components of RH are tabulated in Table 1.

\begin{tabular}{|c|c|}
\hline Components & Ratio \\
\hline Cellulose & $26-35$ \\
\hline Hemicellulose & $17-21$ \\
\hline Lignin & $25-31$ \\
\hline $\mathrm{SiO}_{2}$ (silica) & $15-19$ \\
\hline Solubles & $2-7$ \\
\hline Moisture content & $5-10$ \\
\hline \multicolumn{2}{|c|}{ Table 1:- Components of RH } \\
\hline
\end{tabular}

Burning of rice husk give rice husk ash. Rice husk ash (RHA) contain about $70 \%$ silica in amorphous form and also contain some amount of metallic impurities. One of these important applications is its use as filler in polymer compounds [2-3]. Ali sadr momtazi et al. [4] evaluate the effects of polypropylene fibers and rubber particles on mechanical properties of cement composite containing rice husk ash. In this work,rubber waste particles and rice husk used as a raw materials. Using this raw materials to develop construction materials and to investigate the effect of rubber particles and rice husk addition on the physicalmechanical and water absorption properties of the composites. $0 \%-5 \%$ ranged rubber as replacement to cement in mixtures and $0.3 \%$ polypropylene fiber were used. Elasticity dynamic modulus, compressive and flexural strengths, strain capacity, water absorption and SEM, all of them measured.

D. García et al. [5] made a study about Composites based on sintering rice husk-waste tire rubber mixtures. In this various sizes of rice husk particles were used, which is $0.75 \mathrm{~mm}, 0.37 \mathrm{~mm},>0.1 \mathrm{~mm}$. Due to sintering process rubber mixed with rice husk and composites contain $0-25 \mathrm{wt} \%$ of rice husk. This study proved that the mechanical properties of composites depends, amount and average size fractions of the rice husk particles. Hanafi Ismail et al. [6] study about the effect of a compatibilizer on the mechanical properties and mass swell of white rice husk ash filled natural rubber/linear low density polyethylene blends. Natural rubber (NR)/linear low density polyethylene (LLDPE) filled with white rice husk ash it is blends with and without a compatibilizer, poly propylene-ethylene-acrylic acid (PPEAA).Tensile properties, hardness, and mass swell properties of these composites were investigated in this work. Increasing the loading of WRHA in NR/LLDPE resulted in reduction of tensile strength, elongation at break and mass swell but increased tensile modulus and hardness. 
At a similar composites with the presence of PPEAA increased the tensile strength, tensile modulus, hardness, and elongation at break but reduced the mass swell of the composites. P. Sae-oui et al. [7] reported that in comparison with other fillers like carbon black and silica rice husk ash have better mechanical properties.

Zichao Wei [8] conducted a study about Comprehensive Applications of Rice Husk Biomass. One of the most available and abundant biomasses in the world is rice husks(RHs).In this work, two main components of $\mathrm{RH}$ biomass were extracted one is silica and othere is lignocellulose.

Using calcination method,silica was prepared from RHs.Green phosphor $\mathrm{Zn} 2 \mathrm{SiO} 4: \mathrm{Mn}^{2+}$ prepared from these synthesized silica nanoparticles because of its high reactivity.Doping concentration of $\mathrm{Mn}^{2+}$ and its reaction temperature on the photoluminescence performance of the synthesized phosphors are also discussed in this study. For the second part of this study, Highly light and porous lignocellulose aerogel extracted using ionic liquid 1-Butyl3-methylimidazolium chloride(BMIMCL) and was synthesized via a freeze-thaw process, water regeneration, and $\mathrm{CO}_{2}$ supercritical drying. After surface modification,the lignocellulose aerogel was effective in oil spill adsorption. When the lignocellulose aerogel was pyrolyzed at high temperatures under an inert gas atmosphere, carbon aerogel was prepared which is used for super capacitors.

According to Iara Janaína Fernandes et al. [9] study, Replacement of Commercial Silica by Rice Husk Ash in Epoxy Composites: A Comparative Analysis proved that silica and rice husk ash have similar mechanical properties and water absorption characteristics. Another study Effects of carburized Rice Husk Powders on physical Properties of Elastomer based Materials conducted by Nurettin Akçakale et al. [10] in this work carburized rice husk(CRH) was prepared through Proliz method. This CRH added in SBR (SBR 1502) / waste rubber type elastomer based material. In this way hardness, density, wearing rate, breaking strength, percentage elongation amount and tear strength values of the new compounds were increases.

Mei-Chun Li et study et al. [11] made a Study about Mechanical, Thermal and Friction Properties of Rice Bran Carbon/Nitrile Rubber Composites: Influence of Particle Size and Loading. In this study four type of rice bran carbon(RBC) with different particle size mixed with nitrile rubber (NBR) in a laboratory size two-roll miller. Investigate thermal ,mechanical,frictional properties of the RBC/NBR composites. The tensile strength, tear strength, tensile modulus and abrasion resistance of rubber compounds are increases by the incorporation of carbon black .

\section{BIOFILLER EGGSHELL}

In nature, calcium carbonate seen in the form of sedimentary rocks such as limestone, chalk and in metamorphic marble rocks [12] .They are obtained through quarry or underground mining. Limestone, chalk and marble are mainly contain calcite $[14,15]$. Its major applications in engineering materials, it is used as a fillers in polymer composites [13] and raw materials for cement and mortar production [15]. calcium carbonate in the form of calcite and organic materials such as type $\mathrm{X}$ collagen, sulfated polysaccharides, and other proteins are seen in egg shell $[16,17]$. ES contain different components, these are used for different applications [18-20].ES availability and its chemical composition makes its a main source of filler for Polymer composites.Due to its high thermal and mechanical stability ES is used as a better bio filler in polymer field.

According to Anil Baby et al. [22] made a study on the Mechanical and morphological characterization of carbonized egg-shell fillers/ Borassus fibre reinforced polyester hybrid composites In this,mechanical characteristics of different weight percentages of the carbonized eggshell bio-filler with Borassus flabellifer fruit fibre reinforced polyester composites were investigated and find out its tensile, flexural and impact strength.Using sugar cane matrix and eggshell (ES) filler,a bio based polyethylene has been developed by T. Boronat et al. [23] It has been chemically treated and its potential effect on the development of a biocomposite was analyzed. Interaction between the polyethylene matrix and the eggshell filler improved using titanate particle treatment. The use of titanate as coupling agent enlarges the range of operating temperatures.It also improves the inter facial bonding as it is displayed in impact fracture surface. Analyze the Mechanical, thermal and rheological properties and evaluate the effect of the modified ES loading percentage. Thermal analysis showed a proportional effect of the filler load over the degradation temperature and an inversely effect over the enthalpy. The results showed that the mechanical properties of bio PE effectively improved with modified $\mathrm{CaCO}_{3}$.

Patricio Toro et al. [24] reported that with respect to the particle size,the mechanical properties of polyproplene(PP)-Eggshell(ES) composites have higher tensile modulus than the Polyproplene(PP)-Calcium carbonate $(\mathrm{CC})$ composite.This work conclued that eggshells from aviculture waste can effectively used as a filler for PP composites. Composites made with eggshell show better reinforcement behavior than composites made with traditional calcium carbonate filler, and can also use talc(TA) to a great extent without decreasing the mechanical properties of the PP-TA composites.

\section{CONCLUSION}

Wide ranges of food waste are available in the society.These wastes are the main resources of biofillers.Eco friendly polymer can be created using these type of biofillers.Biofillers are used in polymeric compound because of its low cost and bio degradable nature.Various work showed that composite materials are improved with addition of biofillers compared with convensional fillers.In this study, a number of work have been reviewed and several issues have been addressed regarding the usage of biofillers from rice husk and egg shell,which reinforce polymer composites. 


\section{REFERENCES}

[1]. H. Ismail, M. N. Nasaruddin and H. D. Rozman, "The effect of multifunctional additive in white rice husk ash filled natural rubber compounds," European Polymer Journal, vol. 35(8),pp. 1429-1437, 1999.

[2]. S. Chandrasekhar, P. N. Pramada and L. E. Praveen, "Effect of organic acid treatment on the properties of rice husk silica," Journal of Materials Science., vol. 40(24), pp. 6535-6544, 2005.

[3]. M. N. Nasaruddin and U. S. Ishiaku, "White rice husk ash filled natural rubber compounds: the effect of multifunctional additive and silane coupling agents," Polymer Testing, vol. 18(4), pp. 287-298, 1999.

[4]. A. S. Momtazi and R. Z. Zanoosh, "The effects of polypropylene fibers and rubber particles on mechanical properties of cement composite containing rice husk ash," ProcediaEngineering, vol. 1, pp. 36083615, 2011.

[5]. D. García, J. López, R. Balart, R. A. Ruseckaite and $\mathrm{P}, \mathrm{M}$, Stefani, "Composites based on sintering rice husk-waste tire rubber mixtures," Materials and Design, vol 1, pp. 28,2234-2238,2007.

[6]. H. Ismail, J. M. Nizam and H. P. S. Abdul Khalil, “ The effect of a compatibilizer on the mechanical properties and mass swell of white rice husk ash filled natural rubber/linear low density polyethylene blends", Polymer Testing, vol 20, pp. 125-133, 2001.

[7]. P. Sae-oui, C. Rakdee and P. Thanmathorn, "Use of Rice Husk Ash as Filler in Natural Rubber Vulcanizates: In Comparison with Other Commercial Fillers," Wiley Periodicals, Inc. J Appl Polym Sci" vol. 83, pp. 2485-2493, 2002.

[8]. W. Zichao , "Comprehensive Applications of Rice Husk Biomass," Master's Theses. Vol. 1 pp. 1- 1033, 2016.

[9]. I. Janaína Fernandes, R. Vieira Santos E. C. Araujo dos Santos, T. L . Avila Campos Rocha, "Replacement of Commercial Silica by Rice Husk Ash in Epoxy Composites: A ComparativeAnalysis," Materials Research., vol. 21(3): pp. 531- $562,2018$.

[10]. N. Akçakale and A. İzzet, 'Effects of carburized Rice Husk Powders on physical Properties of Elastomer based Materials" vol. 4093. pp. 49-54,2017.

[11]. M. C. Li, Y. Zhang and U. R. Cho,"Mechanical, Thermal and Friction Properties of Rice Bran Carbon/Nitrile Rubber Comp osites: Influence of Particle Size and Loading," Materials and Design, vol. 63, pp. 565-574, 2014.

[12]. R. J. Gettens, E. W. FitzHugh and R. L. Feller,"Calcium carbonate whites,"Stud. Conserv, vol. 19. pp. 157-184, 1974.

[13]. P. Patnaik,"Handbook of Inorganic Chemicals," McGraw-Hill, ISBN 0-07-049439-8. New York, NY, USA, 2003;

[14]. K. Periasamy and G. C. Mohankumar,'Sea coralderived cuttlebone reinforced epoxy composites: Characterization and tensile properties evaluation with mathematical models," J. Compos. Mater., vol. 50, pp. 807-823, 2016.
[15]. Z. Cao, M. Daly, L. Clémence, L. M. Geever, I. Major, C. L. Higginbotham and D. M. Devine, "Chemical surface modification of calcium carbonate particles with stearic acid using different treating methods," Appl. Surf Sci, vol. 378, pp. 320-329, 2016.

[16]. J. L. Arias, D. J. Fink, S. Q. Xiao, A. Heuer and A. I. Caplan, “ “ Int. Rev. Cytol, vol. 145, pp. 217-223, 1999.

[17]. J. L. Arias, M. S. Fernandez ad C."Materials Characterization,", Vol. 50 (2), pp. 189-195,2003.

[18]. S. I. Ishikawa, K. Suyama, K. Arihara and M. Itoh, "Uptake and recovery of gold ions from electroplating wastes using eggshell membrane, "Bioresource Technology, vol. 81(1), pp. 201-206, 2002.

[19]. S.I. Ishikawa, S. Sekine, N. Miura, K. Suyama, K. Arihara, M. Itoh,'Removal of selenium and arsenic by animal biopolymers,"Biol.Trace Elem. Res, vol. 102, pp. 113-118,2004.

[20]. J. L. Liu, Q. S. Wu, Y. P. Ding and S. Y. Wang,"Biomimetic synthesis of BaSO4 nanotubes using eggshell membrane as template," Journal of Materials Research, vol. 19(10), pp. 2803-2806, 2004.

[21]. J. L. Liu, Q. S. Wu and Y. P. Ding, "Morphologytunable synthesis of SrWO4 crystals via biomimetic supported liquid membrane (SLM) system," Journal of material science, vol. 43,pp. 641-644, 2008.

[22]. Anil Baby, Nayak, S. Y., Heckadka, S. S., Purohit, S., Bhagat, K. K., and Thomas, L. G. (2019). Mechanical and morphological characterization of carbonized egg-shell fillers/Borassus fibre reinforced polyester hybrid composites. Materials Research Express, vol. 6(10), pp. 105-112, 2019.

[23]. T. Boronat, V. Fombuena, D. Garcia-Sanoguera, L. Sanchez-Nacher and R. Balart,'Development of a biocomposite based on green polyethylene biopolymer and eggshell,"Materials \& Design, vol. 68, pp. 177-185, 2015.

[24]. Patricio Toro a,d , Raúl Quijada a,d , Mehrdad Yazdani-Pedram b,d and José Luis Arias," Eggshell, a new bio-filler for polypropylene composites . (CIMAT)," Materials Letters, vol. 61, pp. 4347-4350, 2007. 